Н. В. Волкова, к. п. н., доцент Криворізького державного педагогічного університету

\title{
ІННОВАЦІЙНО-ЗОРІЄНТОВАНИЙ ПІДХІД ЯК ОСНОВА ПІДГОТОВКИ МАЙБУТНІХ ІНЖЕНЕРІВ-ПЕДАГОГІВ У ГАЛУЗІ ХАРЧОВИХ ТЕХНОЛОГІЙ
}

У статті розкрито інновачійно-зорієнтований підхід підготовки майбутніх інженерів-педагогів у галузі харчових технологій. Обтрунтовано необхідність запровадження інноваџійно-зорієнтованого підходу як ефективного засобу підвищення рівня підготовки майбутніх фахівців, даний підхід уможливлює закріплення позитивної мотивачї до опанування знань, умінь $і$ навичок $з$ обраної професї, формування професійної компетентності та стійку потребу в активній діяльності, постійному самовдосконаленні свого професійного образу, активізація позииії майбутнього інженера-педагога у галузі харчових технологій в навчальному призначенні сприяє усвідомленню ним власних можливостей $i$ здібностей, бажання змінювати, удосконалення власного «Я».

Ключові слова: інноваційно-зорієнтований підхід; принциипи; професійна підготовка; стратегія.

Постановка наукової проблеми. Характерними особливостями нашої епохи є динамізм і змінність у всіх аспектах життя. Інформаційне суспільство породжує нову форму економіки - економіку знань, де інтелект, особистісні якості, професіоналізм фахівців стають головними чинниками економічного розвитку та суспільного прогресу. Для того, щоб вижити у сучасному суспільстві людина має набути здатність до адекватного сприйняття нового, пристосування до актуальних змін та їх випередження за рахунок власного ініціювання. У забезпеченні формування інноваційності особистості провідне значення має освіта. Незважаючи на задекларований курс на реформи у вищій освіті, реальний стан освітньої діяльності продовжує тяжіти до традиційних підходів, мало сприятливий для формування й прояву інноваційних властивостей майбутніх фахівців. Отже, дана стаття присвячена проблемі недостатньої зорієнтованості сучасної освітньої підготовки на реалізацію інноваційно-зорієнтованого підходу.

Аналіз останніх досліджень і публікацій Останнім часом питанням інноваційної освітньої діяльності приділяється значна увага науковців. Філософське обгрунтування цілей та цінностей інновацій в сучасній освіті надається в роботах В. Андрущенка, I. Зязюна, В. Кременя та ін. Порівняння традиційної та інноваційної моделей освітньої діяльності проводиться у роботах М. Кларіна, В. Ляудіс. Розробці теорії та практики використання інноваційних навчальних технологій присвячені роботи І. Дичківської, В. Стрельнікова, Д. Чернілевського. У ряді робіт зустрічається словосполучення «інноваційний підхід».

Виділення невирішених частин загальної проблеми. Водночас, цілісне представлення інноваційно-зорієнтованого підходу як основи оптимізації процесу підготовки майбутніх інженерів-педагогів у галузі харчових технологій не знайшло більш глибокого теоретичного обгрунтування.

Метою дослідження с обгрунтування i конкретизація особливостей 
інноваційно-зорієнтованого підходу до підготовки майбутніх інженерівпедагогів у галузі харчових технологій.

Виклад основного матеріалу. Аналіз наукових джерел свідчить про те, що більшість авторів ефективність підготовки майбутніх інженерів-педагогів різних галузей пов'язують 3 посиленням методологічної основи навчання. Особливостями сучасного етапу розвитку освіти є зростання ролі розумової діяльності, перехід до когнітивного суспільства, використання в різних областях людської діяльності, що обумовлює пошук нових підходів до оптимізації підготовки майбутніх фахівців.

Термін «підхід» тлумачиться як сукупність способів, прийомів розгляду чого-небудь, впливу на когось, щось, ставлення до когось, чогось $[0$, с. 471]. Однак, в педагогічній літературі не має єдиного погляду на сутність підходу як методологічної освіти підготовки майбутніх фахівців. Так, З. Меретукова ототожнює поняття «підхід» із поняттями «новий напрям» і «позиція». На іiі думку, «підхід» у поєднанні 3 поняттям «методологічний» може бути розтлумачене як методологічний напрям, як методологічна позиція (від лат. positio - положення, ствердження, точка зору), що $\epsilon$ теоретичним новоутворенням відносно до традиційних методологічних основ» [0, с. 25].

Деякі автори акцентують увагу на багатоаспектності методологічних підходів, оскільки вони сприяють постановці і вирішенню різних проблем. Характеризуючи системний підхід І. Блауберг та Е. Юдін зазначають, що це певний напрям методології спеціально-наукового пізнання i соціальної практики, він сприяє адекватній постановці проблем у конкретних науках i виробленню ефективних стратегій їх вивчення, принципова методологічна орієнтація дослідження, точка зору, 3 якої розглядається об'єкт вивчення (спосіб визначення об'єкта), поняття або принцип, що керує загальною стратегією дослідження [0].

Ряд авторів: І. Блауберг, Е. Юдін, оновлення підготовки сучасних кадрів пов'язують 3 реалізацією підходу, при якому навчальна діяльність стає предметом засвоєння, набуваючи практико-перетворювальний і дослідницький характер, що дозволяє у ході навчання засвоювати новітні види досвіду, створювати нові технології прогнозує мого результату[2].

Сьогодні проблема пошуку шляхів оптимізації підготовки сучасних фахівців, в тому числі інженерів-педагогів у галузі харчових технологій, обумовлює реалізацію підходу, який був би спрямований не тільки на особистість фахівця але і на способи їх інноваційних дій. У процесі професійної підготовки важливо співвідношення інформаційної сторони із орієнтованої основи діяльності майбутніх фахівців у ході навчання.

Інформація, яка структурується у навчальні програми має бути адекватною ситуаційно-моделюючим технологіям, коли зміст навчання полягає не стільки в засвоєнні навчального матеріалу, скільки в практичній діяльності інноваційної спрямованості.

Останнім часом увага вчених (Ю. Гільбух, Я.Пономарьов,С.Сисоваева) акцентується на особистісно-зорієнтованому, креативно-діяльнісному i технологічному підходах, що дозволяе оптимізувати підготовку майбутніх фахівців в умовах вищої освіти. 
У педагогічних дослідженнях об'єктом аналізу виступає освіта й різні аспекти іiі реалізації, наприклад, професійна підготовка як рівень освітньої діяльності. У сучасних умовах суспільного розвитку особливого значення набуває зорієнтованість освіти на формування інноваційних властивостей особистості. За аналогією з особистісно-зорієнтованим підходом, такий підхід в освіті, що надає провідного значення підготовці особистості до життя в змінних умовах, будемо назвати інновачійно-зорієнтованим. Як зазначає М. Кларін: «Значущою особливістю сучасної системи освіти є співіснування двох стратегій організації навчання - традиційної та інноваційної» [0, с. 8-9].

Терміни «традиційне (нормативне) навчання» та «інноваційне навчання» запропоновані групою вчених у доповіді римського клубу (1978), який звернув увагу світової наукової громадськості на неадекватність принципів традиційного навчання вимогам сучасного суспільства до особистості, iii пізнавальних можливостей. Відповідно, надаються такі тлумачення цих двох моделей навчальної діяльності $[0,9]$. Традиційне навчання - зорієнтоване на збереження і відтворення культури, забезпечує стабільність у соціумі за рахунок переважно репродуктивної діяльності учня, формування виконавських здібностей, розвиток уваги і пам'яті. Інноваційне навчання - стимулює новаторські зміни в культурі, соціальному середовищі; орієнтоване на формування готовності особистості до динамічних змін у соціумі за рахунок розвитку здібностей до творчості, різноманітних форм мислення, а також здатності до співробітництва з іншими людьми. Науковці М. Аузіна і А. Возна обгрунтовують призначення інноваційної освіти так: «Основною метою інноваційної освіти є формування і розвиток інноваційної здатності людини». При чому для реалізації цієї мети, на думку авторів, слід забезпечити комплексну модифікацію навчального процесу у вищій школі: «Педагогічні інновації у вищій школі передбачають якісно нові перетворення як цілісного педагогічного процесу, так і його складових, зокрема мотиваційних, змістових, процесуальних та інших структурно-системних компонентів освіти, що призводять до істотного підвищення його результативності та оптимізації. Це діяльність, що пов'язана зі змінами в завданнях, методах і принципах навчання, формах організації навчання та управління цим процесом» [0,9]. Причому, повністю підтримуємо думку авторів про те, що оновлення всіх зазначених компонентів потребує зміни методології навчання, «перехід із суто інформаційних, репродуктивних форм навчання на проблемно-пошукові, індивідуально-диференційовані, особистісно-зорієнтовані 3 акцентом на індивідуалізацію навчальних планів і програм» $[0,11]$.

Усі автори єдині в тому, що сьогодні інновації є основою оптимізації професійної підготовки в системі вищої освіти. Розділяючи цю думку І. Підласий виділяє основні критерії інноваційності навчальних закладів:

1. Навчально-виховний процес базується на принципі природної доцільності і підпорядкованих йому принципах класичної педагогіки.

2. Педагогічна система еволюціонує в гуманістичному напрямі.

3. Організація навчально-виховного процесу не веде до перевантажування учнів і педагогів.

4. Підвищені результати навчально-виховного процесу досягаються не за 
рахунок селекції (відбору) учнів і викладачів, а за рахунок використання нерозкритих і незадіяних можливостей системи.

5. Продуктивність навчально-виховного процесу не $є$ прямим наслідком впровадження дорогих засобів і медіа систем [0, с. 210].

Інноваційно-зорієнтований підхід дозволяє взяття критеріїв інноваційності, як виділяє І. Підласий як основу i основні характеристики інноваційноорієнтованого підходу до майбутніх інженерів-педагогів у галузі харчових технологій. 3 іншої сторони, інноваційно-зорієнтований підхід дозволяє реалізувати спрямованість професійної підготовки на особистість майбутнього інженера-педагога у галузі харчових технологій; акцентувати увагу викладачів на формування професійно-особистісних якостей, які дозволяють активно приймати участь студентів в інноваційній діяльності. Під інноваційнозорієнтованим підходом розуміємо методологічну спрямованість професійної підготовки майбутніх інженерів-педагогів на розвиток їх потреби в новизні нестандартності рішення навчальних проблем, що забезпечує активізацію ї креативних здібностей і готовності, використання інноваційних технологій в практичній діяльності. Цей підхід забезпечує гармонізацію педагогічного впливу i активних дій студентів в навчанні, накопичення досвіду творчого рішення проблем і використання інноваційних технологій для отримання запланованих результатів.

Інноваційно-зорієнтований підхід до професійної підготовки студентів реалізується на основі принципів: інтегративності, неперервності і поступовості розвитку, гуманізму, варіативності, соціального партнерства..

Названі вище принципи дозволили оптимізувати професійну підготовку, надати їй особистісно-зорієнтований і інноваційний характер.

Інноваційно-зорієнтована професійна підготовка майбутніх інженерівпедагогів у галузі харчових технологій являє собою педагогічну систему, спрямовану на підготовку майбутнього фахівця до інноваційної діяльності.

Стратегія інноваційного розвитку як складного процесу, об'єднує у своїй структурі діяльнісний, особистісний та соціальний компоненти.

На рівні діяльнісного компоненту має бути забезпечена максимальна реалізація процесу підготовки інноваційної діяльності, ії творчого, інноваційного характеру. Особистісний компонент спрямований на забезпечення прояву i розвиток інноваційних особистісних властивостей студентів, оволодіння інноваційними технологіями 3 метою вдосконалення переваг i можливостей майбутніх фахівців у галузі харчових технологій. Соціальний компонент забезпечує створення інноваційного навчального середовища, що стимулює творчість, нестандартність дій i інноваційні пошуки майбутніх інженерівпедагогів.

В основу реалізації моделі професійної підготовки майбутніх інженерівпедагогів у галузі харчових технологій покладено такі принципи:

1) принщии інтегративності, що полягає у забезпеченні цілісності i гармонійності розвитку інноваційності майбутніх фахівців;

2) неперервності $i$ nоступовості розвитку, що полягає у постійному оновленню процесу професійної підготовки, відповідності запитам сьогодення;

3) гуманізму, що полягає в пріоритеті під час інноваційної діяльності 
загальнолюдських принципів та забезпечує ціннісну основу інноваційної діяльності;

4) варіативності, що вимагає забезпечення динамізму освітнього середовища, сприяє доланню стереотипів, розширює можливості;

5) соиіального партнерства між усіма учасниками навчального процесу, що забезпечує формування колективних суб' єктів інноваційної діяльності.

Реалізація зазначеної стратегії має розпочинатись вже 3 самого початку навчання у вищому навчальному педагогічному закладі i стосуватись всіх компонентів педагогічної системи - цілемотиваційного, змістового, організаційно-технологічного та контрольно-оцінного:

- цілемотиваційний компонент - зорієнтованість професійної підготовки на формування готовності до інноваційної діяльності, заохочення прояву i розвитку інноваційності майбутніх інженерів-педагогів у галузі харчових технологій;

- змістовий компонент - включення питань щодо інноваційної діяльності у всі навчальні дисципліни професійної підготовки майбутніх інженерівпедагогів у галузі харчових технологій, дотримання сучасних вимог до відбору та подачі навчального матеріалу, а також в особлива змістова побудова навчального процесу, що може здійснюватись як процес інноваційної діяльності;

- організаційно-технологічний компонент - вибір відповідних наявним умовам форм, методів та засобів навчання, а також їх систематизоване використання у вигляді сучасних інноваційних технологій, створення інноваційного освітнього середовища;

- контрольно-оцінний компонент має забезпечувати зворотний зв'язок про результати навчальної діяльності, сприяти розвитку здатності студентів до само- і взаємоконтролю.

Реалізація інноваційно-зорієнтованого підходу у професійній підготовці майбутніх інженерів-педагогів у галузі харчових технологій дозволяє об'єднати всі ऑi компоненти в цілісну систему, яка спрямована на розвиток творчих здібностей студентів та формування їх готовності до інноваційної діяльності.

У змісті інноваційно-зорієнтованому підході співвідносяться знання із професійними уміннями, навичками та якостями, які забезпечують можливість:

- професійного зростання результативної творчої діяльності майбутніх спеціалістів;

- засвоєння дидактичних технологій;

- прийняття нестандартних рішень в навчальних ситуаціях;

- об'єктивна оцінка результатів особистої професійної діяльності;

- проектування подальших перспектив професійного становлення та навчальних звершень.

Аналіз університетської практики дозволяє стверджувати, що інноваційнозорієнтований підхід до професійної підготовки майбутніх інженерів-педагогів у галузі харчових технологій забезпечує: діяльності;

- професійне зростання кожного студента і готовності його до інноваційної

- засвоєння майбутніми інженерами-педагогами у галузі харчових технологій інноваційних освітніх технологій; 
- прийняття нестандартних рішень в ситуаціях професійної спрямованості: об'єктної оцінки результатів власної діяльності;

- проектування подальших перспектив професійного становлення інноваційних досягнень майбутніх фахівців.

Аналіз поглядів різних дослідників $[1,2,5]$ дозволили визначити сутність та особливості інноваційного-зорієнтованого підходу в освіті. Запровадження інноваційного навчання у вищій освіті потребує розробки принципово іншої моделі організації навчального процесу, ключовою відмінністю якої має бути цільова зорієнтованість на підготовку майбутнього інженера-педагога у галузі харчових технологій до життя в умовах сучасного, динамічного суспільства, що забезпечує його становлення як активного суб' єкта змін та інновацій, здатного до самостійної ініціації та реалізації інноваційної діяльності. В основу іiі реалізації можуть бути покладені принципи інтегративності, неперервності і поступовості розвитку, гуманізму, варіативності та соціального партнерства. Дотримання зазначеної стратегії має стосуватись всіх компонентів педагогічної системи: ціле-мотиваційного, змістового, організаційно-технологічного та контрольно-оціночного.

Висновки та перспективи подальших досліджень. Таким чином, інноваційно-зорієнтований підхід до професійної підготовки майбутніх інженерів-педагогів у галузі харчових технологій дозволяє усунути розбіжність між теорією і практикою, між знаннями і досвідом практичної діяльності, що позитивно впливає на якість вищої освіти. Інноваційно-зорієнтований підхід $\epsilon$ внутрішнім механізмом оновлення змісту, методики і технології професійної підготовки студентів, забезпечує постійне зростання творчого потенціалу, розвитку інтелекту, гнучкості мислення, рефлексивних креативних здібностей, готовності до інноваційної діяльності.

Перспективами подальших розвідок буде розробка експериментальних методик впровадження інноваційно-зорієнтованого підходу у підготовку майбутніх інженерів-педагогів у галузі харчових технологій.

\section{ЛІТЕРАТУРА}

1. Аузіна М. О. Інноваційні процеси в освіті: навч. посіб. для студ. вищих навч. закл. / М. О. Аузіна, А. М. Возна. - Національний банк України ; Львівський банківський ін-т. Л. : ЛБІ НБУ, 2003. - $103 \mathrm{c}$.

2. Блауберг И. В. Становление и сущность системного подхода / И.В.Блауберг, Э. Г. Юдин. - М. : Изд-во «Наука», 1973. - 270 с.

3. Власова О. І. Педагогічна психологія: Навч посібник / О. І. Власова. - К. : Либідь, 2005. $-400 \mathrm{c}$.

4. Кларин М. В. Инновации в обучении: метафоры и модели. Анализ зарубежного опыта / М. В. Кларин. - М. : Наука, 1997. - 223 с.

5. Кондрашова Л. В. Высшая педагогическая школа и Болонский процесс: реализации и перспективы / Лидия Валентиновна Кондрашова. - Кривой Рог, 2007. - 474 с.

6. Меретукова 3. К. Методология научного исследования и образования: Учебное пособие для студентов, занимающихся НИР и аспирантов / 3. К. Меретукова. - Майкоп, изд-во АГУ, 2003. -244 с.

7. Ожегов С. И. Словарь русского языка: Ок. 57000 слов / под ред. чл.-корр. АН СССР Н. Ю. Шведовой / С. И. Ожегов. - 18-е изд., стереотип. - М. : Рус. яз., 1987. - 797 с.

8. Подласый И. П. Педагогика. Новый курс: Учебник для студ. пед. вузов. В 2-х кн. / И. П. Подласый. - М. : Гуманит. изд. центр ВЛАДОС, 1999. - Кн. 1 : Общие основы. Процесс обучения. -576 с. 
Н.В.Волкова, к.п.н., доцент Криворожского

государственного педагогического университета

\section{ИННОВАЦИОННО-ОРИЕНТИРОВАННЫЙ ПОДХОД КАК ОСНОВА ПОДГОТОВКИ БУДУЩИХ ИНЖЕНЕРОВ-ПЕДАГОГОВ В ОБЛАСТИ ПИЩЕВЫХ ТЕХНОЛОГИЙ.}

В статье раскрыто инноващионно-ориентированный подход подготовки будущих инженеров-педагогов в области пищевых технологий. Обоснована необходимость введения инновационно-ориентированного подхода как эффективного средства повышения уровня подготовки будущих спечиалистов, данный подход позволяет закрепления положительной мотивации $\kappa$ овладению знаний, умений и навыков по избранной профессии, формирования профессиональной компетентности и устойчивую потребность в активной деятельности, постоянному самосовершенствовании своего профессионального образа, активизаџия позищии будущего инженера-педагога в области пищевых технологий в учебном назначении способствует осознанию им своих возможностей и способностей, желания менять, совершенствование собственного «Я».

Ключевые слова: инновачионно-ориентированный подход, принципь, профессиональная подготовка, стратегия.

Volkova N.V. PhD, associated professor

Krivoy Rog State Pedagogical University.

\section{INNOVATIVE-ORIENTED APPROACH AS A BASIS FOR PREPARATION OF THE FUTURE ENGINEER-TEACHERS IN THE FIELD OF FOOD TECHNOLOGY.}

The article deals with innovative-oriented approach to training of the future engineers and educators in the field of food technology. The necessity of introducing innovative-oriented approach as the effective means of improving training of the future specialists is proved, this approach enables the consolidation of the positive motivation to master the knowledge and skills of chosen profession, the formation of professional competence and steady need for activity, constant self-improvement of the professional image intensification of the future

position of engineer-teacher in the field of food technology in educational purposes promotes awareness of his/her own capacities and abilities, willingness to change, improving his/her own «I». Innovation-oriented approach allows taking innovation criteria. This approach allows to realise the focus on the individual training of the future engineers-teachers in the field of food technology; focus teachers attention on the formation of professional and personal qualities that allow students to actively participate in innovation activities. The innovationoriented approach is understood as the methodological orientation training of the future engineers-teachers on the development of demand for non-standard solutions of educational problems, ensuring the revitalization of their creative ability and readiness to use innovative technologies in practice. This approach ensures harmonization of pedagogical influence and action of students at school, gain experience creative problem solving and the use of innovative technologies for planned results.

Keywords: innovative-oriented approach; principles; training; strategy. 